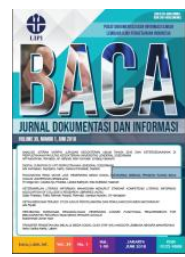

\title{
ANALISIS REFERENSI PADA JURNAL ILMU DAN TEKNOLOGI KAYU TROPIS TAHUN 2013 - 2017
}

\author{
Rahmadani Ningsih Maha ${ }^{1^{*}}$, Tupan $^{2}$ \\ ${ }^{1,2}$ Pusat Data dan Dokumentasi Ilmiah LIPI \\ *Korespondensi: rahmadani.77@gmail.com
}

Diajukan: 18-01-2019; Direview: 19-02-2019; Diterima: 03-03-2019; Direvisi: 15-05-2019

\begin{abstract}
Reference analysis of articles in online journals was conducted, namely Jurnal Ilmu dan Teknologi Kayu Tropis in 2013-2017. The study aims to: (1) find out the distribution of articles and references based on years; (2) know the reference composition based on the type of document; (3) know the patterns of authorship in reference; (4) know the update of the reference year; (5) find out the ranking of journals that are used as references; (6) know the authorship affiliation pattern. The research was carried out by descriptive method. Data was taken from the Journal of Tropical Wood Science and Technology for five years (20132017). Data collection was conducted in October 2018 from the journal webpage available at http://ejournalmapeki.org/index.php/JITKT. Details of each article published, such as the number of articles in each journal number, article distribution, authorship patterns for each article have been recorded and analyzed to make observations. The collected data was compiled and analyzed using an MS-Excel spreadsheet.The results showed that the average number of articles per year was 20,2 and and references per year is 385,8 . The highest reference composition is articles totaling 1063, around 55,11\%.The pattern of authorship shows that more than half of writers prefer to work in collaboration because $51,44 \%$ of citations are multi-authors, while $48,56 \%$ of writers prefer to work in isolation, more reference skills in the span of 0 10 years (current category) namely as many as 1.108 citations/references and 821 citations/references classified as not up-to-date, namely over ten years as many as 821 citations/references. The most used ranking reference journal used by the author was taken from the Journal of Tropical Wood Technology.
\end{abstract}

\begin{abstract}
ABSTRAK
Kajian ini menganalisis referensi artikel pada Jurnal Ilmu dan Teknologi Kayu Tropis tahun 2013-2017, dengan tujuan untuk (1)mengetahui distribusi artikel dan referensi berdasarkan tahun; (2) mengetahui komposisi referensi berdasarkan jenis dokumen; (3) mengetahui pola kepengarangan dalam rujukan; (4) mengetahui kemutakhiran tahun rujukan; (5) mengetahui peringkat jurnal yang dijadikan referensi; (6) mengetahui pola afiliasi kepengarangan. Pengumpulan datanya dari referensi pada Jurnal Ilmu dan Teknologi Kayu Tropis tahun 2013-2017 dan analisis datanya diilakukan metode deskriptif. Hasil penelitian menunjukkan bahwa jumlah rata-rata artikel per tahun adalah 20,2 dan dan referensi per tahun adalah 385,8. Komposis referensi terbanyak adalah artikel sejumlah 1063, sekitar 55,11\%. Pola kepengarangan menunjukkan bahwa lebih dari separuh penulis lebih suka bekerja dalam kolaborasi karena 51,44\% kutipan adalah multi-penulis, sedangkan $48,56 \%$ penulis lebih suka bekerja dalam isolasi. Kemutahiran referensi lebih banyak pada rentang waktu antara 0-10 tahun (katagori mutakhir) sejumlah 1.108 sitiran/referensi dan 821 sitiran/referensi tergolong tidak mutakhir yaitu di atas sepuluh tahun sejumlah $821 \mathrm{sitiran} /$ referensi. Peringkat jurnal rujukan yang terbanyak digunakan penulis diambil dari Jurnal Ilmu Teknologi Kayu Tropis.
\end{abstract}

Keywords: Journal; Tropical wood science; Technology; Bibliometrics; Research collaboration; Reference analysis 


\section{PENDAHULUAN}

Jurnal Ilmu dan Teknologi Kayu Tropis adalah jurnal resmi Masyarakat Peneliti Kayu Indonesia (MAPEKI) yang terbit sejak tahun 2003 berbasis Open Journal System (OJS). Dengan sistem OJS, pengguna informasi penelitian kayu dapat mengakses informasi secara online untuk mendapatkan artikel full-text dan men-submit artikel yang akan diterbitkan. Kontennya berisi artikel asli baik penelitian dasar maupun terapan di bidang ilmu pengetahuan dan teknologi kayu, bahan berlignoselulosa bukan kayu, hasil hutan lainnya dan industri hasil hutan; artikel ulas balik (review) dengan tema yang ditentukan oleh redaksi. Jurnal ini diterbitkan dua kali dalam setahun yaitu Januari dan Juli.

Kajian analisis referensi merupakan bagian dari kajian bibliometrik. Pritchard (1969) mendefinisikan bibliometrik sebagai penerapan metode matematika dan statistik untuk seluruh literatur ilmiah, buku-buku, dan materi lainnya. Analisis bibliometrik berfungsi sebagai instrumen yang berguna dalam menilai sebuah jurnal dan artikelnya. Hal penting yang diperoleh dari kajian analisis referensi ini bahwa peneliti dapat mengetahui karakteristik dari sejumlah rujukan yang digunakan dalam sebuah karya tulis ilmiah.

Kajian ini merupakan sebuah kajian baru yang meneliti tentang karakteristik referensi dari karya tulis ilmiah penelitian kayu. Ada banyak hasil penelitian untuk kajian sitasi dan referensi bidang lain. Pada penelitian ini, penulis belum menemukan rujukan lain untuk objek penelitian khusus ilmu dan teknologi kayu. Penulis tertarik untuk melakukan penelitian ini karena belum ada yang melakukan penelitian referensi pada Jurnal Ilmu dan Teknologi Kayu Tropis. Adapun tujuan penelitian ini, yaitu untuk mengetahui: (1) distribusi artikel dan referensi berdasarkan tahun; (2) komposisi referensi berdasarkan jenis dokumen; (3) pola kepengarangan dalam rujukan; (4) kemutakhiran tahun rujukan; (5) peringkat jurnal yang dijadikan referensi; (6) pola afiliasi kepengarangan.

\section{TINJAUAN PUSTAKA}

\subsection{Jurnal Ilmiah}

Menurut Suryoputro, et al (2012), jurnal ilmiah adalah publikasi yang diterbitkan secara berkala oleh suatu organisasi profesi atau institusi akademik yang memuat artikel artikel produk pemikiran ilmiah secara empiris (artikel hasil penelitian) maupun secara logis (artikel hasil pemikiran) dalam bidang ilmu tertentu. Jurnal ilmiah berisi artikel ilmiah, yaitu laporan yang disusun secara sistematis mengenai hasil kajian atau hasil penelitian yang diperuntukkan bagi masyarakat ilmiah - merupakan peserta khusus dengan tujuan menyampaikan hasil kajian dan kontribusi penulis artikel kepada mereka untuk dipikirkan, dikaji kembali, dan diperdebatkan, baik secara lisan maupun secara tertulis.

Laporan sistematis adalah laporan yang disusun dengan mengikuti struktur dan format yang berlaku dalam suatu jurnal ilmiah, sedangkan kajian adalah hasil pemikiran intensif tentang suatu topik. Hasil penelitian umumnya lebih spesifik karena harus melibatkan data dan dipublikasikan di jurnal ilmiah, laporan dari surat kabar atau majalah, wawancara, laporan saksi mata, dokumen dan sebagainya (Adnan dalam Suryoputro, et al, 2012). Adapun fungsi jurnal ilmiah, yaitu sebagai: (1) sarana komunikasi akademik antara para ilmuwan (dosen/guru); (2) penyebaran (diseminasi) hasil penelitian; (3) pengembangan budaya akademik di perguruan tinggi; (4) penukaran informasi untuk menghasilkan ide baru dalam bidang ilmu pengetahuan dan teknologi. Keberadaan jurnal di perguruan tinggi, berfungsi juga sebagai: (1) sarana pelatihan menulis para dosen; (2) sumber pengetahuan baru; (3) sarana perolehan angka kredit; (4) pengangkatan citra perguruan tinggi (Suryoputro, et al, 2012). 


\subsection{Kolaborasi}

Menurut Handoyo \& Putera (2012), kolaborasi menjadi suatu kata penting dalam meningkatkan popularitas. Adanya kegiatan yang dilakukan secara berkolaborasi agar berdampak pada proses dan hasil yang dicapai. Kolaborasi dapat diartikan sebagai bekerja secara bersama-sama antara dua atau lebih orang atau organisasi untuk mencapai suatu tujuan tertentu. Dalam konteks riset, kolaborasi diperlukan karena tidak selamanya suatu kegiatan riset dapat dilakukan secara individu — sehingga dibutuhkan kerjasama antar-peneliti atau organisasi, baik sumber daya personel, peralatan, dana, maupun gagasan.

Seorang peneliti dapat disebut sebagai kolaborator jika orang tersebut bekerja sama dalam suatu penelitian dan memberikan kontribusi; namanya muncul dalam proposal penelitian asli; bertanggung jawab pada satu atau lebih elemen utama penelitian; pelaksanaan eksperimen; analis dan interpretasi data; penulisan laporan hasil penelitian; bertanggung jawab pada tahap penting penelitian (pencetus ide, hipotesis asli, atau interpretasi teori); sebagai pemilik proposal proyek asli atau penyandang dana, meskipun kontribusi utamanya hanya pada manajemen penelitian (misalnya ketua tim) bukan pada penelitiannya.

Kolaborasi dalam kegiatan riset mendorong berbagi inisiatif untuk mengembangkan kolaborasi diantara peneliti agar mereka dapat melakukan kolaborasi riset, seperti adanya pusat riset unggulan yang mengakomodasi kelompok penelitian di berbagai disiplin ilmu. Tujuan kebijakan pemerintah untuk meningkatkan konektivitas ilmu pengetahuan dan teknologi melalui upaya kolaborasi riset di sektor tertentu, baik antara perguruan tinggi/lembaga litbang maupun dengan industri.

\subsection{Penelitian Terdahulu}

Kajian analisis referensi terhadap jurnal ilmiah pernah dilakukan oleh Kurniawan (2008) yang menganalisis sitiran terhadap Jurnal Fihris tahun 2008. Hasil penelitian menunjukkan bahwa dari 314 sitiran dalam artikel Jurnal Fihris Tahun 2008 terdiri dari 11 jenis literatur dengan rincian: buku sejumlah 131 sitiran (41,72\%), internet 114 sitiran (36,31\%), jurnal 26 sitiran (8,30\%), makalah dan laporan penelitian 24 sitiran (7,64\%), kamus 5 sitiran $(1,60 \%)$, petunjuk 5 sitiran (1,60\%), ensiklopedi 3 sitiran $(0,95 \%)$, majalah 3 sitiran $(0,95 \%)$, glossary 1 sitiran $(0,31 \%)$, undang-undang 1 sitiran $(0,31 \%)$, dan skripsi 1 sitiran $(0,31 \%)$. Terdapat dua jenis bahasa yang digunakan, yaitu bahasa Inggris dan Indonesia, dengan rincian $64,97 \%$ (204) bahasa Inggris dan 35,03\% (110) Bahasa Indonesia.

Junandi (2015) melakukan kajian analisis sitiran karya ilmiah pustakawan Indonesia pada Jurnal Visi Pustaka tahun 2008-2013. Hasilnya menunjukkan bahwa kemutakhiran publikasi karya ilmiah pustakawan yang telah dimanfaatkan dalam Jurnal Visi Pustaka 2008-2013 $(81,37 \%)$, termasuk kategori mutakhir (sepuluh tahun terakhir) setara dengan 166 sitiran $(18,63 \%)$ dan tidak termasuk dalam kategori mutakhir (lebih dari sepuluh tahun terakhir) setara dengan 38 sitiran.

Singh, et al (2011) melakukan penelitian analisis referensi terhadap Journal Documentation dari tahun 1996-2010. Hasil penelitian menunjukkan bahwa jumah dokumen berdasarkan volume selama 15 tahun sejumlah 487 dengan jumlah referensi 15.587 kutipan. Jumlah referensi tertinggi terjadi pada tahun 2009 yaitu 1.884 (12\%) dan paling sedikit terjadi pada tahun 1997 yaitu 343 (2\%). Berdasarkan komposisi jenis referensi menunjukkan bahwa dari 18.324 dokumen yang terbanyak adalah artikel (5.884), prosiding konferensi (998), ulasan (1.075) dan yang lain- buku, editorial, surat, catatan dan survei singkat (10.367). Pola kepengarangan menunjukkan bahwa pola penulis tunggal lebih banyak 
jumlahnya, yaitu 201 (49\%), dua penulis $126(31 \%)$, tiga penulis $55(13 \%)$, dan lebih dari tiga penulis adalah yang terendah yaitu $31(8 \%)$.

Kurniawan (1986) melakukan kajian terhadap 132 artikel pada Journal of Environmental Biology 1980-1984 tentang pola kepengarangan dengan hasil sejumlah 14 judul artikel (10,61\%) merupakan pengarang tunggal dan 118 judul (89,39\%) merupakan artikel yang ditulis secara kolaborasi (berdua dan bertiga). Artikel terbanyak berasal dari perguruan tinggi dan lembaga riset. Chanda \& Superna (2011) mengatakan tentang kajian bibliometrik pada bidang veteriner di India yang diambil dari pangkalan data CABI Abstract periode 2006-2010. Hasilnya menunjukkan bahwa derajat kolaborasi rata-rata diperoleh sebesar 0,84 yang menandakan bahwa penelitian berkolaborasi lebih banyak dilakukan dibandingkan penelitian mandiri.

\section{METODE}

Data penelitian ini yaitu Jurnal Ilmu dan Teknologi Kayu Tropis tahun 2013-2017. Jurnal ini terbit dua kali dalam setahun. Data yang dianalisis sejumlah 10 nomor jurnal. Referensi pada jurnal ini telah diakses pada bulan Oktober 2018 dari halaman web jurnal (http://ejournalmapeki.org/index.php/JITKT). Pengumpulan datanya dilakukan melalui dokumentasi dengan melakukan pencatatan terhadap semua referensi artikel pada jurnal berdasarkan distribusi artikel, jenis dokumen, pola kepengarangan, dan kemutakhiran referensi. Data yang terkumpul, kemudian disusun dan dianalisis secara deskriptif menggunakan MsExcel.

\section{HASIL DAN PEMBAHASAN}

\subsection{Distribusi Artikel dan Referensi Berdasarkan Tahun}

Tabel 1 menunjukkan hasil analisis data distribusi artikel dan referensi yang tersebar selama periode 2013-2017. Hal ini jelas bahwa persentase artikel maksimum pada tahun 2013 dan 2014 dan rujukan maksimum terjadi pada tahun 2017 (Tabel 1).

Tabel 1. Distribusi Artikel dan Referensi Berdasarkan Tahun

\begin{tabular}{|c|c|c|c|c|}
\hline Periode & $\begin{array}{c}\text { Jumlah } \\
\text { Artikel }\end{array}$ & $\begin{array}{c}\text { Persentase } \\
\text { artikel/tahun }\end{array}$ & $\begin{array}{c}\text { Jumlah } \\
\text { Referensi }\end{array}$ & $\begin{array}{c}\text { Persentase (\%) } \\
\text { Referensi/Artikel }\end{array}$ \\
\hline 2013 & 22 & 21,78 & 348 & 18,04 \\
\hline 2014 & 22 & 21,78 & 377 & 19,54 \\
\hline 2015 & 19 & 18,81 & 417 & 21,62 \\
\hline 2016 & 18 & 17,82 & 366 & 18,97 \\
\hline 2017 & 20 & 19,80 & 421 & 21,82 \\
\hline Total & 101 & 100 & 1.929 & 100 \\
\hline Rata-rata & 20,2 & - & 385,8 & - \\
\hline
\end{tabular}

Sedangkan persentase artikel dan rujukan minimum terjadi pada tahun 2016. Jumlah rata-rata artikel per-tahun adalah 20 dan referensi per-tahun adalah 386. Singh, et al (2011) melakukan analisis referensi terhadap Journal Doumentation dari tahun 1996-2010. Hasil penelitian menunjukkan bahwa jumah dokumen berdasarkan volume selama 15 tahun adalah sejumlah 487 dengan jumlah referensi 15.587 kutipan. Jumlah referensi tertinggi terjadi pada tahun 2009, yaitu 1.884 (12\%) dan paling sedikit terjadi pada tahun 1997, yaitu 343 (2\%). 


\subsection{Komposisi Referensi Berdasarkan Jenis Dokumen}

Tabel 2 menunjukkan hasil analisis data referensi per tahun berdasarkan jenis dokumen yang dibedakan menjadi tiga jenis, yaitu artikel, prosiding, dan sumber lain, seperti buku teks, skripsi, tesis, standar, dan laporan. Jumlah artikel maksimum adalah 270 pada tahun 2015 dan minimum 178 pada tahun 2013. Rujukan artikel terbanyak yaitu sejumlah $1.063(55,11 \%)$. Hal tersebut dapat dilihat pada Tabel 2.

Tabel 2. Komposisi Referensi Berdasarkan Jenis Dokumen

\begin{tabular}{|c|c|c|c|c|}
\hline \multirow{2}{*}{ Tahun } & \multicolumn{3}{|c|}{ Jenis Dokumen } & Jumlah \\
\cline { 2 - 4 } & Jurnal & Prosiding & Sumber lainnya & Referensi \\
\hline 2013 & 178 & 29 & 141 & 348 \\
\hline 2014 & 204 & 23 & 150 & 377 \\
\hline 2015 & 270 & 18 & 129 & 417 \\
\hline 2016 & 186 & 12 & 168 & 366 \\
\hline 2017 & 225 & 17 & 179 & 421 \\
\hline Total & 1.063 & 99 & 767 & 1.929 \\
\hline Persentase (\%) & 55,11 & 5,13 & 39,76 & 100 \\
\hline
\end{tabular}

\subsection{Pola Kepengarangan dalam Referensi}

Tabel 3 menunjukkan bahwa penulis tunggal jumlahnya lebih besar dari penulis kolaborasi (dua, tiga, dan seterusnya). Jika dibandingkan penulis tunggal dengan penulis lebih dari satu digabungkan maka jumlah penulis yang lebih dari satu berjumlah lebih banyak. Penulis satu sejumlah 509 (26,39\%) dan penulis dua sampai lebih dari enam jika digabungkan sejumlah 1.241 (64,33\%). Hal ini menunjukkan bahwa lebih dari separuh penulis lebih menyukai bekerja dalam kolaborasi karena $51,44 \%$ kutipan adalah multi-penulis, sedangkan $48,56 \%$ penulis lebih menyukai bekerja dalam isolasi (mandiri).

Tabel 3. Pola Kepengarangan

\begin{tabular}{|c|c|c|c|c|c|c|}
\hline Pola Penulis & 2013 & 2014 & 2015 & 2016 & 2017 & Jumlah \\
\hline Satu & 93 & 87 & 89 & 113 & 127 & 509 \\
\hline Dua & 70 & 82 & 95 & 70 & 71 & 388 \\
\hline Tiga & 66 & 61 & 83 & 69 & 75 & 354 \\
\hline Empat & 39 & 57 & 51 & 40 & 30 & 217 \\
\hline Lima & 21 & 30 & 36 & 17 & 31 & 135 \\
\hline Enam & 8 & 16 & 20 & 5 & 12 & 61 \\
\hline$>6$ & 16 & 13 & 23 & 9 & 25 & 86 \\
\hline Tanpa Pengarang & 0 & 0 & 3 & 0 & 0 & 3 \\
\hline Institusi & 35 & 31 & 17 & 43 & 50 & 176 \\
\hline Total & 348 & 377 & 417 & 366 & 421 & 1.929 \\
\hline
\end{tabular}

\subsection{Kemutakhiran Rujukan Berdasarkan Tahun}

Tabel 4 menganalisis data berdasarkan tahun rujukan, yang terbagi menjadi tiga periode yaitu 0-5 tahun terakhir, 6-10 tahun terakhir, dan di atas 10 tahun. Jumlah maksimum yang dijadikan rujukan adalah lebih besar di atas 10 tahun terakhir. 
Tabel 4. Tahun Rujukan 3 Periode

\begin{tabular}{|c|c|c|c|c|}
\hline Tahun & $0-5$ tahun & $6-10$ tahun & $>10$ tahun & $\begin{array}{c}\text { Jumlah } \\
\text { Referensi }\end{array}$ \\
\hline 2013 & 102 & 119 & 127 & 348 \\
\hline 2014 & 134 & 100 & 143 & 377 \\
\hline 2015 & 126 & 140 & 151 & 417 \\
\hline 2016 & 84 & 77 & 205 & 366 \\
\hline 2017 & 117 & 109 & 195 & 421 \\
\hline Total & 563 & 545 & 821 & 1.929 \\
\hline
\end{tabular}

Tabel 4 menunjukkan bahwa kemutahiran referensi lebih banyak pada rentang waktu antara 010 tahun dengan kategori mutakhir sejumlah 1.108 sitiran/referensi, dan 821 sitiran/referensi tergolong tidak mutakhir di atas sepuluh tahun sejumlah 821 sitiran/referensi.

\subsection{Peringkat Jurnal}

Tabel 6 menunjukkan Jurnal Ilmu dan Teknologi Kayu Tropis yang banyak dirujuk oleh penulis. Jurnal ini memiliki keteraturan dalam penerbitannya dan mengkaji penelitian kayu dari berbagai subyek, tidak khusus mengkaji anatomi kayu atau kimia kayu. Para peneliti yang memiliki kepakaran di ilmu kayu dari berbagai aspek dapat menuliskan hasil penelitiannya pada jurnal. Jurnal ini berbahasa Indonesia sehingga memudahkan bagi para peneliti pemula untuk memahami literatur di bidangnya dengan lebih baik. Selain itu, jurnal ini telah terakreditasi nasional, sehingga baik dari segi konten maupun fisik sudah diakui secara nasional. Dari 1.063 artikel yang dirujuk ada sejumlah 474 judul jurnal yang dijadikan referensi.

Tabel 6 mengurutkan judul jurnal yang memiliki persentase di atas 1\%. Apabila diperhatikan setiap jurnal cukup minim jumlah persentase rujukan karena luasnya bidang subyek yang ditulis pada jurnal yang mencakup ilmu dan teknologi kayu tropis.

Tabel 6. Peringkat Jurnal yang Dirujuk

\begin{tabular}{|c|l|c|c|c|c|c|c|c|}
\hline No & \multicolumn{1}{|c|}{ Nama Jurnal } & $\mathbf{2 0 1 3}$ & $\mathbf{2 0 1 4}$ & $\mathbf{2 0 1 5}$ & $\mathbf{2 0 1 6}$ & $\mathbf{2 0 1 7}$ & Jumlah & $\begin{array}{c}\text { Persentase } \\
\text { (\%) Artikel }\end{array}$ \\
\hline 1 & $\begin{array}{l}\text { Jurnal Ilmu Teknologi } \\
\text { Kayu Tropis }\end{array}$ & 5 & 14 & 10 & 19 & 21 & 69 & 6,49 \\
\hline 2 & $\begin{array}{l}\text { Jurnal Penelitian Hasil } \\
\text { Hutan }\end{array}$ & 3 & 6 & 13 & 2 & 17 & 41 & 3,85 \\
\hline 3 & Holz Roh-Werkst & 15 & 3 & 7 & 2 & 4 & 31 & 2,92 \\
\hline 4 & $\begin{array}{l}\text { Jurnal Ilmu dan Teknologi } \\
\text { Hasil Hutan }\end{array}$ & 2 & 3 & 7 & 12 & 4 & 28 & 2,63 \\
\hline 5 & For.Prod.J & 7 & 7 & 3 & 7 & 3 & 27 & 2,54 \\
\hline 6 & Biores.Technol. & 2 & 18 & 0 & 1 & 3 & 24 & 2,45 \\
\hline 7 & J Wood Sci & 6 & 5 & 7 & 2 & 4 & 24 & 2,26 \\
\hline 8 & Holzforschung & 5 & 1 & 5 & 5 & 5 & 21 & 1,98 \\
\hline 9 & Wood Sci Technol & 7 & 2 & 6 & 5 & 1 & 21 & 1,98 \\
\hline 10 & Ann. For. Sci. & 1 & 4 & 8 & 0 & 2 & 15 & 1,41 \\
\hline 11 & Wood Fiber Sci. & 1 & 3 & 5 & 4 & 1 & 14 & 1,31 \\
\hline 12 & Jurnal Teknik Sipil & 0 & 5 & 1 & 1 & 6 & 13 & 1,13 \\
\hline 13 & Bio Resources & 2 & 1 & 3 & 3 & 2 & 11 & 1,03 \\
\hline
\end{tabular}




\subsection{Pola Afiliasi Kepengarangan}

Berdasarkan Tabel 7 terlihat bahwa pola afiliasi kepengarangan pada Jurnal Ilmu Teknologi Kayu Tropis terbanyak terjadi pada tahun 2013, yaitu sejumlah 47 lembaga yang berafiliasi. Kemudian disusul tahun 2014 ada sejumlah 42 lembaga, tahun 2017 sejumlah 29 lembaga, tahun 2015 dan 2016 masing-masing sejumlah 28 lembaga.

Tabel 7. Afiliasi Kepengarangan Tahun 2013-2017

\begin{tabular}{|c|c|}
\hline Tahun & Jumlah Afiliasi Lembaga \\
\hline 2013 & 47 \\
\hline 2014 & 42 \\
\hline 2015 & 28 \\
\hline 2016 & 28 \\
\hline 2017 & 29 \\
\hline
\end{tabular}

Tabel 8 menunjukkan ada pola hubungan atau kolaborasi penulis tahun 2013 yang memiliki jumlah maksimum berafiliasi.

Tabel 8. Pola Afiliasi Kepengarangan 2013

\begin{tabular}{|c|c|c|c|}
\hline $\begin{array}{l}\text { Tahun } \\
2013 \\
\text { No.1 }\end{array}$ & Afiliasi Lembaga & $\begin{array}{l}\text { Tahun } \\
2013 \\
\text { No.2 }\end{array}$ & Afiliasi Lembaga \\
\hline \multirow[t]{3}{*}{ Penulis 1} & Puslit Biomaterial LIPI & Penulis 1 & Puslit Biomaterial LIPI \\
\hline & & & Fakultas MIPA-IPB \\
\hline & & & $\begin{array}{l}\text { Puslitbang Keteknikan } \\
\text { Kehutanan\&Pengolahan Hasil Hutan, } \\
\text { Bogor }\end{array}$ \\
\hline \multirow[t]{2}{*}{ Penulis 2} & $\begin{array}{l}\text { Faculty of Forestry, Gadjah } \\
\text { Mada University }\end{array}$ & Penulis 2 & Politeknik Pertanian Negeri Kupang \\
\hline & & & Fakultas Kehutanan IPB \\
\hline \multirow[t]{4}{*}{ Penulis 3} & $\begin{array}{l}\text { IPB (Fakultas Kehutanan, } \\
\text { Pertanian) }\end{array}$ & & $\begin{array}{l}\text { Koordinasi Perguruan Tinggi Swasta } \\
\text { Wilayah I Sumatera Utara }\end{array}$ \\
\hline & & & Fakultas Kehutanan IPB \\
\hline & & & $\begin{array}{l}\text { Puslitbang SDH Perum PerhutaniCepu } \\
\text { Jawa Tengah }\end{array}$ \\
\hline & & & $\begin{array}{l}\text { Fakultas Pertanian Universitas } \\
\text { Sumatera Utara }\end{array}$ \\
\hline \multirow[t]{3}{*}{ Penulis 4} & $\begin{array}{l}\text { Balai Besar Penelitian } \\
\text { Dipterokarpa, Samarinda }\end{array}$ & & $\begin{array}{l}\text { Fakultas Kehutanan, Universitas } \\
\text { Gadjah Mada }\end{array}$ \\
\hline & $\begin{array}{l}\text { Puslitbang Keteknikan } \\
\text { Kehutanan \& Pengolahan Hasil } \\
\text { Hutan, Bogor }\end{array}$ & & \\
\hline & $\begin{array}{l}\text { Dinas Kehutanan Kabupaten } \\
\text { Katingan, Kalimantan Tengah }\end{array}$ & & \\
\hline \multirow[t]{2}{*}{ Penulis 5} & $\begin{array}{l}\text { Fakultas Kehutanan, Universitas } \\
\text { Gajah Mada }\end{array}$ & Penulis 5 & $\begin{array}{l}\text { Puslitbang Keteknikan Kehutanan \& } \\
\text { Pengolahan Hasil Hutan, Bogor }\end{array}$ \\
\hline & & & Fakultas Kehutanan IPB \\
\hline \multirow[t]{3}{*}{ Penulis 6} & Fakultas Kehutanan IPB & & $\begin{array}{l}\text { Puslitbang Keteknikan Kehutanan \& } \\
\text { Pengolahan Hasil Hutan, Bogor }\end{array}$ \\
\hline & & & Fakultas Kehutanan IPB \\
\hline & & & $\begin{array}{l}\text { Puslitbang Keteknikan Kehutanan \& } \\
\text { Pengolahan Hasil Hutan, Bogor }\end{array}$ \\
\hline
\end{tabular}




\begin{tabular}{|c|c|c|c|}
\hline & & & Fakultas Kehutanan IPB \\
\hline \multirow[t]{3}{*}{ Penulis 7} & $\begin{array}{l}\text { Fakultas Pertanian Universitas } \\
\text { Lampung }\end{array}$ & Penulis 7 & Fakultas Kehutanan IPB \\
\hline & Fakultas Kehutanan IPB & & Fakultas Pertanian IPB \\
\hline & & & Kangwon National University, Korea \\
\hline \multirow[t]{2}{*}{ Penulis 8} & $\begin{array}{l}\text { Puslitbang Keteknikan } \\
\text { Kehutanan \& Pengolahan Hasil } \\
\text { Hutan, Bogor }\end{array}$ & & $\begin{array}{l}\text { Fakultas KehutananUniversitas } \\
\text { Lambung Mangkurat }\end{array}$ \\
\hline & & & Fakultas Kehutanan IPB \\
\hline \multirow[t]{3}{*}{ Penulis 9} & Fakultas Kehutanan IPB & Penulis 9 & Fakultas Kehutanan IPB \\
\hline & $\begin{array}{l}\text { Puslitbang Keteknikan } \\
\text { Kehutanan \& Pengolahan Hasil } \\
\text { Hutan, Bogor }\end{array}$ & & $\begin{array}{l}\text { Fakultas Pertanian Universitas } \\
\text { Sumatera Utara }\end{array}$ \\
\hline & & & Fakultas Kehutanan IPB \\
\hline \multirow[t]{5}{*}{$\begin{array}{l}\text { Penulis } \\
10\end{array}$} & Puslit Biomaterial LIPI & $\begin{array}{l}\text { Penulis } \\
10\end{array}$ & $\begin{array}{l}\text { Fakultas Pertanian Universitas } \\
\text { Sumatera Utara }\end{array}$ \\
\hline & & & UPT Biomaterial LIPI \\
\hline & & & Fakultas Kehutanan, Unhas \\
\hline & & & $\begin{array}{l}\text { Kementerian Kehutanan Republik } \\
\text { Indonesia }\end{array}$ \\
\hline & & & Fakultas Kehutanan IPB \\
\hline \multirow[t]{3}{*}{$\begin{array}{l}\text { Penulis } \\
11\end{array}$} & $\begin{array}{l}\text { Puslitbang Permukiman } \\
\text { Bandung }\end{array}$ & $\begin{array}{l}\text { Penulis } \\
11\end{array}$ & Fakultas Kehutanan IPB \\
\hline & & & Pusat Studi Biofarmaka, IPB \\
\hline & & & Fakultas Kedokteran Hewan, IPB \\
\hline
\end{tabular}

Gambar 1 menunjukkan pola afiliasi penulis artikel tahun 2013 yang memiliki jumlah minimum (348) namun memiliki pola afiliasi terbanyak dengan lembaga lain. Instansi yang paling banyak berafiliasi dengan lembaga lain adalah Fakultas Kehutanan IPB dan Pusat Penelitian Biomaterial LIPI di urutan kedua. 


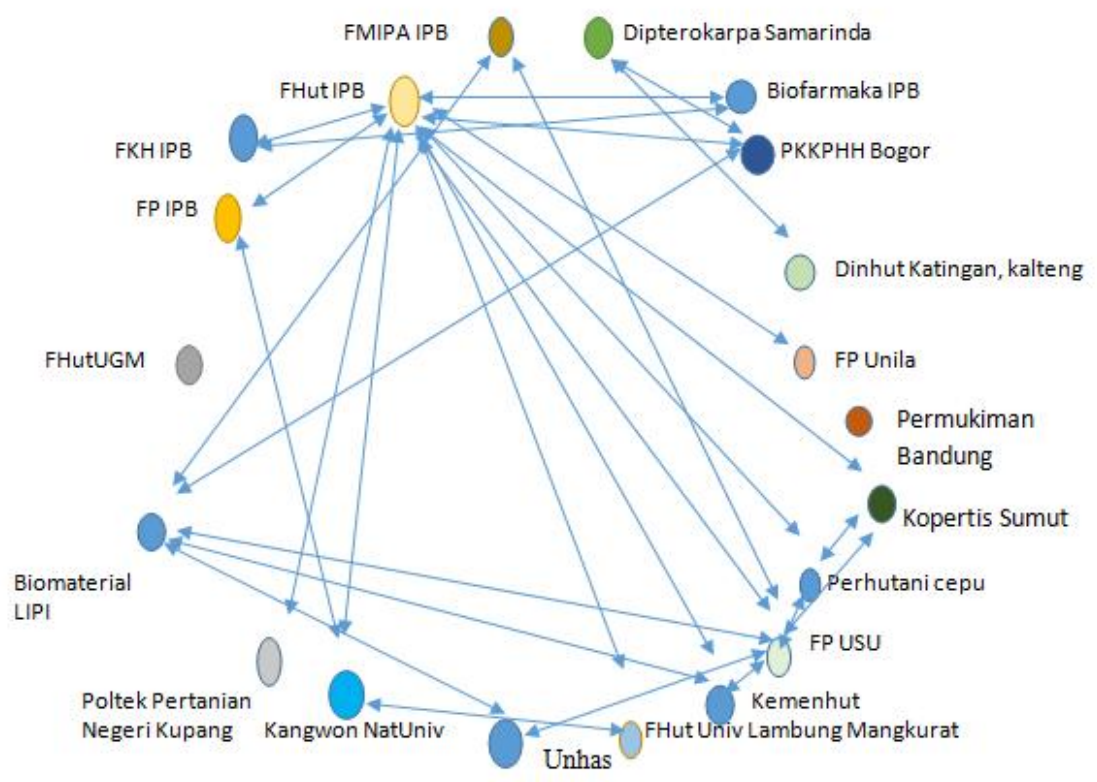

Gambar 1. Pola afiliasi penulis tahun 2013

\section{KESIMPULAN}

Dari hasil dan pembahasan dapat disimpulkan bahwa jumlah rata-rata artikel Jurnal Ilmu Teknologi Kayu Tropis per-tahun adalah 20 dan referensi per-tahun adalah 385,8. Komposisi referensi terbanyak adalah artikel sejumlah $1.063(55,11 \%)$. Pola kepengarangan menunjukkan bahwa sebagian besar penulis melakukan kolaborasi (51,44\%), dan 48,56\% penulis melakukannya secara mandiri. Kemutakhiran referensi lebih banyak pada rentang waktu antara 0-10 tahun, dengan jumlah 1.108 sitiran/referensi, dan 821 sitiran/referensi tergolong tidak mutakhir. 


\section{DAFTAR PUSTAKA}

Arya, C. \& Sharma, S. 2011. Authorship Trends and Collaborative Research in Veterinary Sciences: A Bibliometric Study. Chinese Librarianship: An International Electronic Journal, 34.

Kurniawan, Fauzan Dwi. 2008. Analisis Sitiran Terhadap Jurnal Fihris Tahun 2008 dan Ketersediaan Koleksi di Perpustakaan UIN Sunan Kalijaga Yogyakarta. Berkala llmu Perpustakaan dan Informasi 9 (1), 20-30.

Handoyo, Setiowiji \& Putera, Prakoso Bhairawa. 2012. Tingkat Kolaborasi Peneliti pada Program Insentif "Semi Top-Down" Kementerian Riset dan Teknologi Tahun 2008-2010. Warta KIML Vol. 10, No. 2, 99-114.

Kumar Singh, Neeraj, Sharma, Jyoti, \& Kaur, Navneet. 2011. Citation Analysis of Journal of Documentation. Webology 8 (1).

Kumar, N. 1986. Literature Contribution in Journal of Environmental Biology: A Bibliometric Study. Annals of Library Science and Documentation, 33 (1-2), 31-40.

Soplantila, Peggy Antonette. 2017. Analisis Bibliometrika Menggunakan Kaidah Lotka pada Produktivitas Penulis Artikel Bidang Pertanian Di Indonesia. Bogor: Sekolah Pascasarjana Institut Pertanian Bogor.

Junandi, Sri. 2015. Analisis Sitiran Karya Ilmiah Pustakawan Indonesia pada Jurnal Visi Pustaka Tahun 2008-2013.

Suryoputro, Gunawan, Riadi, Sugeng, \& Sya'ban, Ali. 2012. Menulis Artikel untuk Jurnal Ilmiah. Jakarta: Uhamka Press. 